\title{
Effects of iron limitation on carbon balance and photophysiology of the Antarctic diatom Chaetoceros cf. simplex
}

\author{
Deborah Bozzato $^{1,2}$ (D) $\cdot$ Torsten Jakob $^{1}$ (D) Christian Wilhelm ${ }^{3} \cdot$ Scarlett Trimborn $^{4,5}$ (D)
}

Received: 14 March 2020 / Revised: 3 December 2020 / Accepted: 5 December 2020 / Published online: 5 January 2021

(c) The Author(s) 2021

\begin{abstract}
In the Southern Ocean (SO), iron (Fe) limitation strongly inhibits phytoplankton growth and generally decreases their primary productivity. Diatoms are a key component in the carbon (C) cycle, by taking up large amounts of anthropogenic $\mathrm{CO}_{2}$ through the biological carbon pump. In this study, we investigated the effects of $\mathrm{Fe}$ availability (no $\mathrm{Fe}$ and $4 \mathrm{nM} \mathrm{FeCl}_{3}$ addition) on the physiology of Chaetoceros cf. simplex, an ecologically relevant SO diatom. Our results are the first combining oxygen evolution and uptake rates with particulate organic carbon (POC) build up, pigments, photophysiological parameters and intracellular trace metal (TM) quotas in an Fe-deficient Antarctic diatom. Decreases in both oxygen evolution (through photosynthesis, P) and uptake (respiration, R) coincided with a lowered growth rate of Fe-deficient cells. In addition, cells displayed reduced electron transport rates (ETR) and chlorophyll a (Chla) content, resulting in reduced cellular POC formation. Interestingly, no differences were observed in non-photochemical quenching (NPQ) or in the ratio of gross photosynthesis to respiration (GP:R). Furthermore, TM quotas were measured, which represent an important and rarely quantified parameter in previous studies. Cellular quotas of manganese, zinc, cobalt and copper remained unchanged while Fe quotas of Fe-deficient cells were reduced by $60 \%$ compared with High Fe cells. Based on our data, Fe-deficient Chaetoceros cf. simplex cells were able to efficiently acclimate to low Fe conditions, reducing their intracellular Fe concentrations, the number of functional reaction centers of photosystem II (RCII) and photosynthetic rates, thus avoiding light absorption rather than dissipating the energy through NPQ. Our results demonstrate how Chaetoceros cf. simplex can adapt their physiology to lowered assimilatory metabolism by decreasing respiratory losses.
\end{abstract}

Keywords Southern Ocean $\cdot$ Phytoplankton $\cdot$ Trace metals $\cdot$ Primary production $\cdot$ Respiration

Supplementary Information The online version of this article (https://doi.org/10.1007/s00300-020-02785-1) contains supplementary material, which is available to authorized users.

Deborah Bozzato

d.bozzato@rug.nl

1 Institute of Biology, Plant Physiology, University of Leipzig, Leipzig, Germany

2 Groningen Institute for Evolutionary Life Sciences, University of Groningen, Groningen, The Netherlands

3 Saxon Institute of Biotechnology, Leipzig, Germany

4 Biogeosciences Section, EcoTrace, Alfred Wegener Institute, Helmholtz Centre for Polar and Marine Research, Bremerhaven, Germany

5 Marine Botany Department, Faculty 2 Biology/Chemistry, University of Bremen, Bremen, Germany

\section{Introduction}

The Southern Ocean (SO) is the world's largest high nutrients, low chlorophyll (HNLC) region. In this region, despite the abundant supply of macronutrients such as $\mathrm{N}$ and $\mathrm{P}$, phytoplankton growth and primary production are mainly limited by the trace element iron $(\mathrm{Fe})$. Numerous studies have revealed the important role of $\mathrm{Fe}$ in phytoplankton growth (Boyd et al. 2007; Smetacek et al. 2012), since Fe is required as an important co-factor in enzymes involved in photosynthesis, respiration and nitrogen fixation. Since 1990, numerous laboratory Fe enrichment experiments have been performed, both with Antarctic natural phytoplankton communities (e.g. Feng et al. 2010; Hoppe et al. 2013; Trimborn et al. 2015, 2017) and single phytoplankton species (e.g. van Oijen et al. 2004; van de Poll et al. 2011; Petrou et al. 2014; Trimborn et al. 2019) to unravel the physiological effects of Fe limitation. Fe limitation usually decreases 
Photosystem II (PSII) efficiency (Fv/Fm), relative electron transport rate (rETR) and net primary production (NPP) (Hoppe et al. 2013; Zhu et al. 2016; Yoon et al. 2018). Moreover, Fe limitation also controls the photoacclimation status by lowering pigment quotas like chlorophyll a (Chla) and fucoxanthin (van Oijen et al. 2004; Pankowski and McMinn 2009; Feng et al. 2010). Besides these general physiological adjustments, the acclimation to $\mathrm{Fe}$ limitation enhances taxon-specific photophysiological differences, for example between haptophytes and diatoms. These different photophysiological acclimation strategies of the two taxa were attributed to the habitats they occupy: diatoms usually thrive in waters with a shallow mixed layer depth, thereby experiencing higher irradiance levels, whereas haptophytes like Phaeocystis antarctica are better adapted to low irradiance levels found in a deeply mixed water column (Arrigo and van Dijken 2003).

It is estimated that diatoms contribute to about $40 \%$ of marine primary production (Sarthou et al. 2005; Tréguer et al. 2018), playing a key role in the ocean carbon (C) cycle, particularly in the SO. Indeed, the SO is an important net sink for atmospheric $\mathrm{CO}_{2}$ (Gruber et al. 2019). Many studies have tried to estimate the contribution of phytoplankton to carbon sequestration by quantifying NPP using models, satellite remote sensing data or measured ${ }^{14} \mathrm{C}$ uptake rates (Arrigo et al. 2008; Takao et al. 2012; Hoppe et al. 2018). Nevertheless, a lack of knowledge remains about an important parameter, namely the respiratory losses of organic $\mathrm{C}$ by phytoplankton. In order to improve NPP estimates of a given ecosystem, not only should photosynthetic $\mathrm{C}$ fixation be considered, but also respiratory $\mathrm{C}$ losses by phytoplankton. Due to the differences in day length, light availability and seasonal changes in salinity, the contribution of respiration to the total carbon balance is highly dynamic (Verity 1982; Serret et al. 2015). Although considerable effort has been expended on understanding photosynthesis in aquatic systems, the measurement of phytoplankton respiratory losses has received less attention, primarily due to methodological limitations. While numerous datasets of ${ }^{14} \mathrm{C}$ uptake measurements are available for SO phytoplankton (e.g. Tortell et al. 2008; Kropuenske et al. 2009; Trimborn et al. 2015), only few studies have investigated the respiratory losses together with the assimilation of C (e.g. Tilzer and Dubinsky 1987; Gleitz and Thomas 1992; Thomas et al. 1992; Regaudie-deGioux and Duarte 2012; Trimborn et al. 2014). Information on $\mathrm{C}$ fixation or respiration rates exists, but rarely have both been measured during the same experiment. The following two studies are emblematic of this issue. In the first study, C uptake measurements were coupled with photophysiological and respiration measurements, however POC production rates were not determined (Trimborn et al. 2014). In the second study, ${ }^{14} \mathrm{C}$ uptake measurements were combined with photophysiological responses and POC build up, but in this case information about respiration was missing (Petrou et al. 2014). Estimates on respiration rates remain rare yet, as a consequence, respiration data commonly used in models are rough estimates or assumptions (Laws and Bannister 1980; Geider et al. 1998). Thus, respiration in the World's oceans remains a large unknown factor of the global $\mathrm{C}$ budget (Marra 2009; Moisan and Mitchell 2018).

Among the plethora of phytoplankton species inhabiting the SO, we have chosen a representative of the genus Chaetoceros, which is an important diatom in the SO. In the present study, the effect of low Fe availability on photosynthesis rates $\left(\mathrm{O}_{2}\right.$ evolution and POC build up), respiratory losses $\left(\mathrm{O}_{2}\right.$ uptake rates), intracellular TM quotas of $\mathrm{Fe}$, zinc $(\mathrm{Zn})$, manganese $(\mathrm{Mn})$, cobalt $(\mathrm{Co})$ and copper $(\mathrm{Cu})$ and the photoacclimation status (pigments, photophysiological parameters) were determined in an Antarctic strain of Chaetoceros cf. simplex. To our knowledge, no laboratory experiments have explicitly investigated all these processes together in an Antarctic diatom under Fe limitation.

\section{Materials and methods}

\section{Experimental conditions}

The Antarctic diatom Chaetoceros cf. simplex used in this study was isolated in 1999 by Thomas Mock (obtained from Dr. Steffi Gäbler-Schwarz, AWI Bremerhaven, Germany). This culture is not axenic, but unialgal and frequently diluted with fresh culture medium. Using inverted light microscopy, no bacteria were observed in the stock culture or during the experiment. The culture was kept for more than 6 months in stock cultures with Fe-deplete and -replete natural Antarctic seawater medium. For the preacclimation phase (over 2 weeks) and the main experiment, the diatom was grown at $2{ }^{\circ} \mathrm{C}$ in semi-continuous dilute cultures at an irradiance (E) equal to $100 \mu \mathrm{mol}$ photons $\mathrm{m}^{-2} \mathrm{~s}^{-1}$ with a $16: 8 \mathrm{~h}$ light:dark cycle, using light-emitting diodes (LED) lamps (SolarStinger LED SunStrip Marine Daylight, Econlux). Irradiance measurements were integrated in the visible part of the electromagnetic spectrum $(400-700 \mathrm{~nm})$, i.e. Photosynthetically Active Radiation (PAR), henceforth referred to as $\mathrm{E}_{\mathrm{PAR}}$, using a 4p-sensor (Walz, Effeltrich, Germany) connected to a LI-1400 datalogger (Li-Cor, Lincoln, NE, United States). The $\mathrm{F} 2{ }_{\mathrm{R}}{ }^{-1}$ medium (Guillard and Ryther 1962) was prepared from sterile-filtered $(0.2 \mu \mathrm{m})$ natural low-Fe $\left(0.12 \mathrm{nmol} \mathrm{L}^{-1}\right)$ Antarctic seawater (sampled during the Antarctic Circumpolar Expedition, January 1st, 2017, 59 $61^{\prime} \mathrm{S} 148^{\circ} 64^{\prime} \mathrm{W}$ ), supplemented with chelexed (ChelexR 100, Sigma-Aldrich, Merck) macronutrients $\left(100 \mu \mathrm{mol} \mathrm{L}^{-1}\right.$ $\left.\mathrm{Si}, 100 \mu \mathrm{mol} \mathrm{L}-1 \mathrm{NO}_{3}, 6.25 \mu \mathrm{mol} \mathrm{L}{ }^{-1} \mathrm{PO}_{4}\right)$ and vitamins ( $30 \mathrm{nmol} \mathrm{L}^{-1} \mathrm{~B}_{1}, 23 \mathrm{nmol} \mathrm{L}^{-1} \mathrm{~B}_{7}$, and $0.228 \mathrm{nmol} \mathrm{L}^{-1} \mathrm{~B}_{12}$ ). Two different trace metal mix were added to this seawater: 
either (i) a trace metal mix containing no Fe (Low Fe treatment) or (ii) an addition of $4 \mathrm{nM} \mathrm{FeCl}_{3}$ (High Fe treatment). The trace metal mixture contained zinc $\left(0.16 \mathrm{nmol} \mathrm{L}{ }^{-1}\right)$, copper $\left(0.08 \mathrm{nmol} \mathrm{L}^{-1}\right)$, cobalt $\left(0.09 \mathrm{nmol} \mathrm{L}^{-1} \mathrm{Co}\right)$, molybdenum $\left(0.05 \mathrm{nmol} \mathrm{L}^{-1}\right)$, and manganese $\left(1.9 \mathrm{nmol} \mathrm{L}^{-1}\right)$. These trace metal additions were adjusted to maintain the ratio of the original $\mathrm{F} 2^{-1}$ recipe and represent trace metal concentrations typical for Antarctic HNLC waters. 4-L polycarbonate incubation bottles (Nalgene, Thermo Fisher Scientific, Waltham, MA USA) were used and triplicates of each treatment were run in parallel. Over the experiment, cells grew in exponential growth phase and were harvested at cell densities of 49,228 \pm 3299 and 33,496 \pm 1094 cells $\mathrm{mL}^{-1}$ for the Low Fe and High Fe treatment, respectively. Seawater carbonate chemistry remained stable over the whole duration of the experiment (Online Resource 1). The main experiment lasted 8 days for the Low Fe treatment and 7 days for the High Fe treatment.

In order to minimize Fe contamination, all sampling and handling of the incubation bottles were conducted under a laminar flow hood (Class 140 100, Opta, Bensheim, Germany) using trace metal clean techniques. Briefly, all culture bottles were soaked for 1 week in $1 \%$ Citranox solution (Sigma-Aldrich, St. Louis, MO, USA) and subsequently for another 1 week in $1 \mathrm{M}$ hydrochloric acid (high-performance liquid chromatography grade, Merck Millipore Corporation). Between each soaking step, the bottles were rinsed seven times with ultrapure water (Merck Millipore Corporation). Finally, the trace metal-cleaned equipment/bottles were air dried under a clean bench (U.S. class 100) and stored in three polyethylene (PE) bags until usage.

\section{Determination of total dissolved iron concentrations and cellular trace metals quotas}

All labware used for analysis was pre-cleaned according to the GEOTRACES cookbook (Cutter et al. 2017). To determine the concentration of total dissolved $\mathrm{Fe}(\mathrm{dFe})$ in the Antarctic seawater, all culture medium (without cells) and incubation (with cells) bottles of each treatment were sampled at the end of the experiments. To this end, $100 \mathrm{~mL}$ of each sample were filtered (HCl-cleaned $0.2-\mu \mathrm{m}$ polycarbonate filters, $47 \mathrm{~mm}$, Nuclepore, Whatman, GE Healthcare, Chicago, IL, USA) using a trace metal clean filtration system under a laminar flow hood (Class 100, Opta, Bensheim, Germany). The filtrate was then filled into a $125-\mathrm{mL} \mathrm{HCl}$-cleaned PE bottle and stored triplebagged at $2{ }^{\circ} \mathrm{C}$ until analysis. Between each filtration, the filtration system was cleaned in an acid bath with $1 \mathrm{M} \mathrm{HCl}$ and rinsed with Milli-Q. Prior to dFe analysis, all $0.2 \mu \mathrm{m}$ prefiltered seawater samples were acidified to $\mathrm{pH} 1.7$ with sub-boiled $\mathrm{HNO}_{3}$ (distilled $65 \% \mathrm{HNO}_{3}$, pro analysis,
Merck) and irradiated for $1.5 \mathrm{~h}$ using a UV power supply system (7830) and photochemical lamp (7825) from ArcGlass to provide total dissolved concentrations of $\mathrm{Cu}$ and $\mathrm{Co}$ (Biller and Bruland 2012). Mn, Fe, Co, Cu and Zn concentrations in seawater samples were analyzed via external calibration using a SeaFAST system (Elemental Scientific) coupled to an Element2 (Thermo Scientific) mass spectrometer. Standards for external calibration were prepared from natural iron-poor seawater spiked with commercially available ICP-MS single element standards (SCP Science; $1000 \mathrm{mg} \mathrm{L}^{-1}$ ). This procedure reduced possible interference by the matrix and enabled analysis of low concentrations of the elements of interest. To assess the accuracy and precision of the method, a NASS-7 (National Research Council of Canada) reference standard was also analyzed in a 1:10 dilution (corresponding to environmentally representative concentrations) at the beginning and end of a batch run $(n=5)$. Recoveries for Fe were equal to $2.00 \pm 0.02 \mathrm{mg} \mathrm{g}^{-1}$, with no significant differences between the measured and certified values of the NASS-7 (i.e., $1.85 \pm 0.19 \mathrm{mg} \mathrm{g}^{-1}$ ).

To determine intracellular TM (Fe, $\mathrm{Zn}, \mathrm{Mn}, \mathrm{Co}$ and $\mathrm{Cu})$ contents, phytoplankton cells were collected onto $0.2-\mu \mathrm{m}$ acid-cleaned PC filters (EMD Millipore, Darmstadt, Germany), and rinsed for $15 \mathrm{~min}$ with a $0.1 \mathrm{M}$ oxalic acid wash to remove trace metals bound to the cell surface (Hassler and Schoemann 2009). Finally, the filters were rinsed with filtered seawater and placed into TM-cleaned $30-\mathrm{mL}$ polytetrafluoroethylene (PTFE) vials. Intracellular TM contents were subsequently analyzed via ICP-MS following a digestion with $\mathrm{HNO}_{3}$ and $\mathrm{HF}$ (Ho et al. 2003; Twining and Baines 2013) in a pressure digestion system (PicoTrace, DAS 30). All filters were digested for $16 \mathrm{~h}$ at $180{ }^{\circ} \mathrm{C}$ using $5 \mathrm{~mL}$ of sub-boiled $\mathrm{HNO}_{3}$ (distilled $65 \%$, p.a., Merck) and $0.5 \mathrm{~mL}$ of HF (ROTIPURAN® Ultra $48 \%$, Carl Roth) followed by the addition of $1 \mathrm{~mL}$ of Milli-Q water. The volume of the cell extract was then evaporated on a $140{ }^{\circ} \mathrm{C}$ hot plate and the evaporated was passed through a $\mathrm{NaOH}$ solution, which effectively neutralized it. $0.2 \mathrm{~mL}$ of subboiled $\mathrm{HNO}_{3}$ (distilled 65\%, p.a., Merck) and $0.8 \mathrm{~mL}$ of Milli-Q water were then added and the solution was heated to $50{ }^{\circ} \mathrm{C}$ for $4 \mathrm{~h}$ to resuspend the cell extract before it was transferred into $10-\mathrm{mL}$ TM cleaned polypropylene (PP) vials. Lastly, $10 \mu \mathrm{L}$ of $\mathrm{Rh}\left(1 \mathrm{mg} \mathrm{\textrm {L } ^ { - 1 }}\right)$ was added as internal standard and the volume was brought up to $10 \mathrm{~mL}$ using Milli-Q water, before subsequent analysis on a high resolution ICP-MS (Element2, Thermo Scientific). Acid (5 mL of sub-boiled $\mathrm{HNO}_{3}, 0.5 \mathrm{~mL} \mathrm{HF}$ ) and two filter blanks as well as the BCR-414 (Plankton reference material, Sigma Aldrich, St. Louis, MO, United States) samples were also processed and analyzed in order to assure low background TM values as well as digestion quality. Intracellular TM contents were then normalized per cell or POC. 


\section{Fluorescence measurements}

Chlorophyll a (Chla) fluorescence was measured with a fast repetition rate fluorometer (FRRf, FastOcean PTX sensor, Chelsea Technologies Group Ltd, West Molesey, UK) connected with a FastAct Laboratory system (Chelsea Technologies Group Ltd). All measurements were performed at $2{ }^{\circ} \mathrm{C}$ after a $10 \mathrm{~min}$ dark acclimation period. The excitation wavelength of the fluorometer's LED was $450 \mathrm{~nm}$, with an automated adjustment of the $\mathrm{E}_{\mathrm{PAR}}$ to $1.2 \times 10^{22} \mu \mathrm{mol}$ photons $\mathrm{m}^{-2} \mathrm{~s}^{-1}$. A single turnover mode was set with a saturation phase consisting of 100 flashlets on a $2 \mu$ s pitch followed by a relaxing phase of 40 flashlets on a $50 \mu$ s pitch. According to Kolber et al. (1998), photosynthetic efficiency was determined by measuring the minimum (Fo) and maximum fluorescence (Fm) to calculate the maximum quantum yield of photochemistry in PSII (Fv/Fm) using the following equation:

$F \mathrm{v} / F \mathrm{~m}=(F \mathrm{~m}-F \mathrm{o}) / F \mathrm{~m}$

For the measurement of photosynthesis versus irradiance curves $(P-E$ curves), five actinic light levels $(21,50$, $107,207,415 \mu \mathrm{mol}$ photons $\mathrm{m}^{-2} \mathrm{~s}^{-1}$ ) alternating with dark periods were applied for $5 \mathrm{~min}$ each. The effective (see below) and the maximum quantum yields were measured six times at the end of each light and dark period, respectively. The FRRf device supplied actinic irradiance and the irradiance level was previously checked with a light sensor (ULM-500 Universal Light Meter equipped with a Spherical Micro Quantum Sensor US-SQS, Walz GmbH, Effeltrich, Germany). Absolute electron transport rates (aETR, $\mathrm{e}^{-}$PSII $^{-1} \mathrm{~s}^{-1}$ ) at each light level were calculated following Suggett et al. (2004, 2009):

$\operatorname{aETR}=\sigma \mathrm{PSII} \cdot\left(\left(F \mathrm{q}^{\prime} / F \mathrm{~m}^{\prime}\right) /(F \mathrm{v} / F \mathrm{~m})\right) \cdot E$

where $\sigma \mathrm{PSII}$ is the functional absorption cross section of PSII photochemistry $\left(\mathrm{nm}^{2} \mathrm{PSII}^{-1}\right) . F \mathrm{q}^{\prime} F \mathrm{~m}^{\prime-1}$ denotes the effective PSII quantum yield under ambient light and $\mathrm{E}$ represents the respective irradiance level ( $\mu$ mol photons $\mathrm{m}^{-2} \mathrm{~s}^{-1}$ ). Using the Stern-Volmer equation, non-photochemical quenching (NPQ) of Chla fluorescence was calculated as $\left(F \mathrm{~m} F \mathrm{~m}^{\prime-1}\right)-1$ (Bilger and Björkman 1990).

The photosynthesis-irradiance $(P-E)$ curves based on fluorescence measurements were fitted according to Eilers and Peeters (1988). The fitting parameters $a, b$, and $c$ describe the influence of photoinhibition, the saturation level, and the initial slope of the $P-E$ curve, respectively. Hereby, the term 'photoinhibition' is related to a decrease of photosynthetic activity at PSII due to excessive degradation of the D1 protein particularly at high irradiance (Murata et al. 2007). In the fluorescence measurements, photoinhibition leads to a quenching of $\mathrm{Chl}$ a fluorescence indicated by a decrease of
PSII quantum yield and accordingly by a decrease of aETR (Horton et al. 1994). The maximum absolute transport rate $\left(\mathrm{aETR}_{\max }\right)$ and the light-saturating index $\left(\mathrm{E}_{\mathrm{k}}\right)$ were calculated as:

$\mathrm{aETR}_{\max }=1 / b+2 \sqrt{a \cdot c}$

$E_{\mathrm{k}}=c / b+2 \sqrt{a \cdot c}$

In addition to the parameters named above, the analysis software of the FRRf FastPro8 (Chelsea Technologies Group Ltd, West Molesey, UK) provides a measure of the connectivity factor of adjacent PSII light harvesting complexes (P, dimensionless), the functional absorption cross section of PSII's photochemistry ( $\left.\sigma \mathrm{PSII}, \mathrm{nm}^{2}\right)$ and the number of functional PSII reaction centers per volume $\left(\mathrm{RCII}_{\mathrm{vol}}, \mathrm{nmol} \mathrm{m}^{-3}\right)$. The latter parameter was then normalized to cell number to obtain cellular concentrations of RCII ( $\left.\mathrm{RCII}_{\text {cell }}, \mathrm{amol} \mathrm{cell}^{-1}\right)$.

After the completion of the $P-E$ curve, an additional dark-adaptation period of $10 \mathrm{~min}$ was applied, followed by a single turnover flashlet to check for recovery of PSII. Using the $F \mathrm{v} / F \mathrm{~m}$ measured before and after the $P-E$-curve, the yield recovery was calculated and given as $\%$ of the initial $F \mathrm{v} / F \mathrm{~m}$ (before the $P-E$-curve). All measurements $(n=3)$ were conducted at the growth temperature of $2{ }^{\circ} \mathrm{C}$.

\section{Oxygen-based photosynthesis and respiration rates}

Photosynthesis and respiration rates were measured using an oxygen microsensor system (PreSens, Regensburg, Germany). From each experimental condition, cells were harvested by gentle filtration of $400-500 \mathrm{~mL}$ culture over a 2- $\mu \mathrm{m}$ membrane filter (Isopore, Millipore) to obtain a volume of about 4-6 $\mathrm{mL}$ (equal to a Chla concentration of $2-3 \mu \mathrm{g} \mathrm{mL}^{-1}$ ). Subsequently, the concentrated cell suspension was transferred into a special custom-made cuvette where an implantable oxygen microsensor was placed (PreSens) and maintained at $2{ }^{\circ} \mathrm{C}$ under continuous gentle stirring. For the measurement of the oxygenbased $P-E$ curves, Chaetoceros cf. simplex cells were dark-adapted for $10 \mathrm{~min}$ and then exposed for $5 \mathrm{~min}$ to each of five increasing $\mathrm{E}_{\mathrm{PAR}}(45,90,185,302,455 \mu \mathrm{mol}$ photons $\mathrm{m}^{-2} \mathrm{~s}^{-1}$ ), alternating with a 5 min dark phase between each increasing $\mathrm{E}_{\mathrm{PAR}}$. The $\mathrm{E}_{\mathrm{PAR}}$ was provided by a light projector equipped with neutral density filters. Each $\mathrm{E}_{\mathrm{PAR}}$ was checked with a light sensor as described above (subsection "Determination of total dissolved iron concentrations and cellular trace metals quotas"). After the measurements, samples were taken for determination of Chla concentration of the cell's concentrate, filtered onto $\mathrm{GF} / \mathrm{F}$ filters and stored at $-80^{\circ} \mathrm{C}$. Chla was subsequently extracted in $1.6 \mathrm{~mL}$ acetone (overnight in darkness, $4{ }^{\circ} \mathrm{C}$ ) 
and determined with a calibrated Turner Designs fluorometer (Model 10-000 R, Mt. View, Canada).

Photosynthetic rates were calculated using the oxygen solubility as a function of the growth medium's salinity and the measuring temperature (Benson and Krause 1984). Gross oxygen production (GP) and net oxygen production (NP) are reported in $\mu \mathrm{mol} \mathrm{O}_{2}(\mathrm{mg} \mathrm{Chla})^{-1} \mathrm{~h}^{-1}$. GP was derived by correcting the net oxygen evolution rate for the corresponding dark respiration rate $\left[\mathrm{R} ; \mu \mathrm{mol} \mathrm{O}_{2}(\mathrm{mg} \mathrm{Chla})^{-1} \mathrm{~h}^{-1}\right]$. $\mathrm{GP}_{\max }$ and $\mathrm{NP}_{\max }$ in the following sections refer to GP and NP values obtained at the maximal $\mathrm{E}_{\mathrm{PAR}}$ investigated (i.e., $455 \mu \mathrm{mol}$ photons $\mathrm{m}^{-2} \mathrm{~s}^{-1}$ ). The $P-E$ curves based on gross oxygen production were fitted according to Eilers and Peeters (1988).

\section{Growth and cell size determination}

Cell samples were fixed with Lugol's solution and stored at $2{ }^{\circ} \mathrm{C}$ in the dark until counting. Cell numbers were determined using Utermöhl chambers (Hydrobios, Altenholz, Germany) on an inverted microscope (Zeiss Axiovert 200). After a settling time of at least $24 \mathrm{~h}$, Chaetoceros cf. simplex cells were counted in stripes in an Utermöhl chamber until at least 400 cells had been counted. A magnification of $\times 400$ in combination with a $\times 1.6$ optovar was used for counting. The cell numbers were plotted on a logarithmic scale and the slope of the linear regression was used to determine growth rates (Fanesi et al. 2016). Cellular biovolume was calculated according to Hillebrand et al. (1999), measuring at least 50 cells for each treatment.

\section{Particulate organic carbon and nitrogen content}

For the analyses of particulate organic carbon (POC) and particulate organic nitrogen (PON) content, at the end of the experiment $750 \mathrm{~mL}$ of each Chaetoceros cf. simplex culture flask were filtered onto pre-combusted $\left(500{ }^{\circ} \mathrm{C}, 15 \mathrm{~h}\right)$ 25-mm GF/F filters (Whatman). One filter blank was taken for each sampled bottle. Samples were stored in combusted glass petri dishes at $-20{ }^{\circ} \mathrm{C}$ until sample preparation. Prior to the analysis, filters were dried at $60{ }^{\circ} \mathrm{C}$ overnight before they were acidified with $200 \mu \mathrm{L}$ of $0.2 \mathrm{M} \mathrm{HCl}$ to remove the inorganic $\mathrm{C}$. After being dried again at $60^{\circ} \mathrm{C}$ overnight, filters were coated in tin foil and compressed into small pellets. Samples were analysed with an automated carbon-nitrogen elemental analyser (Euro EA-CN Elemental Analyzer, HEKAtech GmbH, Wegberg, Germany). POC and PON contents were corrected for blank measurements and normalized to cell density and the filtered volume to yield cellular quotas. Daily POC production rates were calculated by multiplication of the cellular quota with the specific growth rate of the respective treatment. The molar ratio of cellular carbon to nitrogen $(\mathrm{C}: \mathrm{N})$ was calculated by dividing the cellular content of POC (mol) by the cellular content of PON (mol).

\section{Analysis of pigments}

For the analysis of pigments, $750 \mathrm{~mL}$ of each Chaetoceros cf. simplex incubation were filtered onto $25-\mathrm{mm}$ glass fiber filters (GF/F, Whatman). The filters were frozen immediately in liquid nitrogen $\left(\mathrm{N}_{2}\right)$ and stored at $-80^{\circ} \mathrm{C}$. Before analysis, pigments were extracted from the GF/F filters for $24 \mathrm{~h}$ at $4{ }^{\circ} \mathrm{C}$ in the dark using $90 \%$ acetone (v/v). After centrifugation $\left(5 \mathrm{~min}, 4{ }^{\circ} \mathrm{C}, 13000 \mathrm{~g}\right)$ and filtration through a $0.45-\mu \mathrm{m}$ pore size nylon syringe filter $(\mathrm{Nalgene} \circledast$, Nalge Nunc 241 International, Rochester, NY, USA), total pigment concentrations were determined via reverse HPLC (LaChromElite system, VWR, Darmstadt, Germany). A Spherisorb ODS-2 column (5- $\mu \mathrm{m}$ particle size; Waters, Milford, MA, USA) was used for the separation of the pigments, applying a gradient following Wright et al. (1991). Peaks were detected at $440 \mathrm{~nm}$ and identified as well as quantified by co-chromatography with standards (DHI Lab Products, Hørsholm, Denmark) using the software EZChrom Elite ver. 3.1.3. (Agilent Technologies, Santa Clara, CA, USA). More specifically, concentrations of the light harvesting pigments (LHP): chlorophyll a (Chla), chlorophyll c2 (Chl c2), fucoxanthin (Fuco), and the light protective pigments (LPP) diatoxanthin (Dt), diadinoxanthin (Dd) and $\beta$-carotene were determined and normalized to filtered volume and cell numbers to yield cellular quotas.

\section{Statistics}

The effect of Fe availability (Low Fe vs. High Fe) on all experimental parameters was statistically analyzed using one-way analyses of variance (ANOVA) with Bonferroni's multiple comparison post-tests. All statistical analyses were performed using the program GraphPad Prism (Version 5.00 for Windows, Graph Pad Software, San Diego California, USA) and the significance testing was done at the $p<0.05$ level.

\section{Results}

\section{Chlorophyll a-based fluorescence parameters}

Fe availability strongly influenced the photophysiology of Chaetoceros cf. simplex (Table 1, Bozzato 2019). The maximum PSII quantum yield of dark-adapted cells $(F \mathrm{v} / F \mathrm{~m})$ was significantly lower $(p<0.001)$ in the Low Fe than in the High Fe treatment. The same trend was also observed for the connectivity between adjacent PSIIs (P), where P in the Low Fe treatment was significantly lower, by $27 \%$, than $\mathrm{P}$ in the 
Table 1 Chla fluorescence-based photophysiological parameters in Chaetoceros cf. simplex for low $\mathrm{Fe}$ and high $\mathrm{Fe}$ conditions

\begin{tabular}{lll}
\hline & Low Fe & High Fe \\
\hline$F \mathrm{v} / F \mathrm{~m}$ (rel. unit) & $0.38 \pm 0.01$ & $0.50 \pm 0.01^{*}$ \\
$\mathrm{P}($ rel. unit) & $0.32 \pm 0.03$ & $0.44 \pm 0.02^{*}$ \\
$\mathrm{RCII}_{\text {cell }}($ amol cell \\
$\sigma_{\text {PSII }}\left(\mathrm{nm}^{2}\right)$ & $0.60 \pm 0.02$ & $0.81 \pm 0.05^{*}$ \\
\hline
\end{tabular}

Values represent mean \pm standard deviation $(n=3)$. Significant changes $(p<0.05$, ANOVA) relative to the low $\mathrm{Fe}$ condition are denoted by *

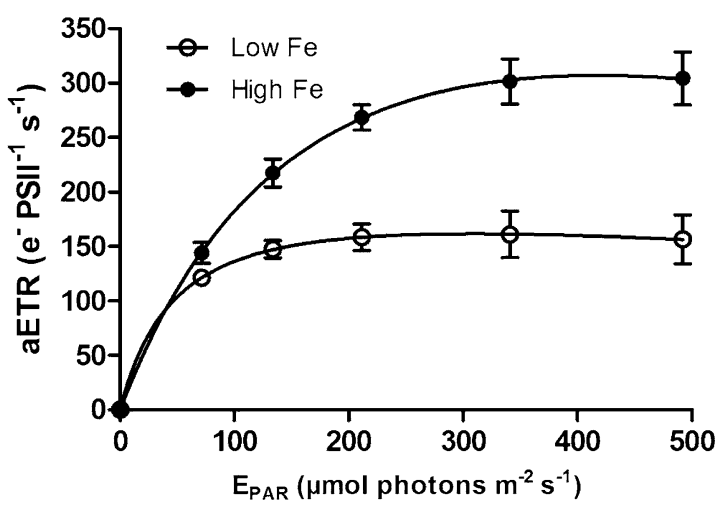

Fig. 1 Absolute electron transport rates (aETRs) in Chaetoceros cf. simplex grown under Low Fe (open circle) and High Fe (filled circle) conditions. Values represent mean \pm standard deviation $(n=3)$

High Fe treatment $(p<0.001)$. Similarly, the concentrations of functional reaction centers of PSII per cell $\left(\mathrm{RCII}_{\text {cell }}\right)$ were significantly lower, by $26 \%$, in the Low Fe compared to the High $\mathrm{Fe}(p<0.001)$. In contrast, the functional absorption cross sections of PSII, $\sigma_{\mathrm{PSII}}$, were $10 \%$ higher in the Low Fe than in the High Fe treatment.

The absolute electron transport rates (aETRs) showed a clear difference between Low Fe and High Fe treatments (Fig. 1). Particularly, the maximum absolute electron transport rates $\left(\mathrm{aETR}_{\max }\right)$ of the Low Fe were almost double the High Fe treatment rates, rising from $156 \pm 22$ to $304 \pm 24$ $\mathrm{e}^{-}$PSII $^{-1} \mathrm{~s}^{-1}$. aETRs determined at the growth $\mathrm{E}_{\mathrm{PAR}}$ $\left(\mathrm{aETR}_{100}\right)$ were also significantly lower in the Low Fe compared to the High Fe treatment (Table 2).

The photoacclimation parameter $E_{\mathrm{k}}$ (derived from Chla fluorescence-based $P-E$ curves) revealed a different light acclimation status of Chaetoceros cf. simplex cells, depending strongly on $\mathrm{Fe}$ availability. Accordingly, the $E_{\mathrm{k}}$ value was more than three times greater under High $\mathrm{Fe}$ compared to Low Fe availability (Table 2). However, this did not affect the sensitivity to photoinhibition as values of $\mathrm{Fv} / \mathrm{Fm}$ recovery remained unaltered (Table 2).
Table 2 Photophysiological parameters aETR $_{100}$ (determined at $100 \mu \mathrm{mol}$ photons $\mathrm{m}^{-2} \mathrm{~s}^{-1}$ ), $\mathrm{E}_{\mathrm{k}}$ and $\mathrm{Fv} / \mathrm{Fm}$ recovery $(\%)$ were determined in Chaetoceros cf. simplex grown under low $\mathrm{Fe}$ and high $\mathrm{Fe}$ conditions

\begin{tabular}{lll}
\hline & Low Fe & High Fe \\
\hline $\mathrm{aETR}_{100}\left(\mathrm{e}^{-}\right.$PSII $\left.^{-1} \mathrm{~s}^{-1}\right)$ & $136.8 \pm 7.2$ & $183.3 \pm 11.2^{*}$ \\
$E_{\mathrm{k}}\left(\mu \mathrm{mol}\right.$ photons $\left.\mathrm{m}^{-2} \mathrm{~s}^{-1}\right)$ & $33.8 \pm 8.2$ & $124.2 \pm 30.0^{*}$ \\
$F \mathrm{v} / F \mathrm{~m}$ recovery $(\%)$ & $46.9 \pm 1.5$ & $51.0 \pm 1.8$ \\
\hline
\end{tabular}

Values represent mean \pm standard deviation $(n=3)$. Significant changes $(p<0.01$, ANOVA) relative to the Low $\mathrm{Fe}$ condition are denoted by *

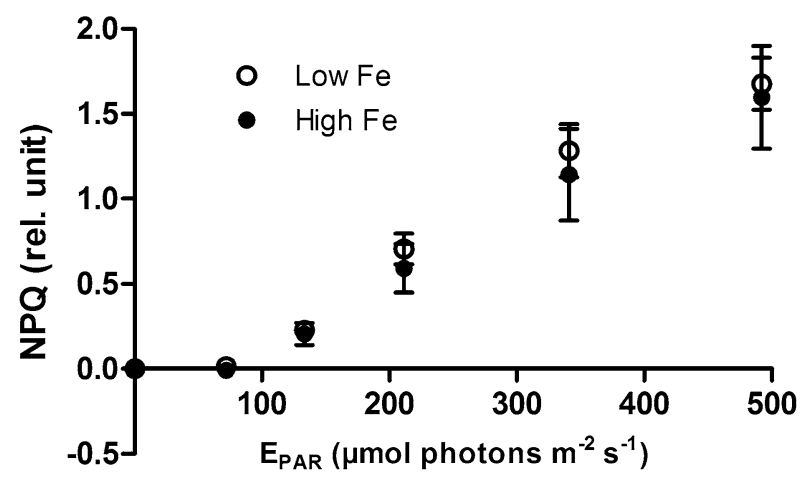

Fig. 2 Non-photochemical quenching (NPQ) in Chaetoceros cf. simplex for Low $\mathrm{Fe}$ (open circle) and High Fe (filled circle) conditions. Values represent mean \pm standard deviation $(n=3)$

Also, the light-induced NPQ of Chaetoceros cf. simplex cells was not influenced by the different $\mathrm{Fe}$ conditions (Fig. 2).

\section{Oxygen-based photosynthesis and respiration rates}

Unfortunately, the relatively low Chla concentrations used in the GP and NP measurements caused a low signal/noise ratio and resulted in large standard deviations (Fig. 3, Table 3). Nevertheless, the measured differences between both treatments followed the same trend as aETR measured by Chla fluorescence, i.e. GP and NP of the Low Fe treatment were significantly lower compared to the High Fe treatments. As depicted in Fig. 3a, $\mathrm{GP}_{\max }$ in the Low Fe treatment was only $24 \%$ of the $\mathrm{GP}_{\max }$ in the High Fe treatment, reaching rates of $95 \pm 28$ and $399 \pm 224 \mu \mathrm{mol} \mathrm{O}_{2}(\mathrm{mg} \mathrm{Chla})^{-1} \mathrm{~h}^{-1}$ in Low Fe and High Fe conditions, respectively. An even greater difference between Low $\mathrm{Fe}$ and High $\mathrm{Fe}$ conditions was measured in net photosynthesis (NP) rates (Fig. 3b), with $\mathrm{NP}_{\max }$ values of $287 \pm 224$ and $55 \pm 28 \mu \mathrm{mol} \mathrm{O}_{2}(\mathrm{mg} \mathrm{Chla})^{-1} \mathrm{~h}^{-1}$, respectively. Please note that all values reported in Table 3 were determined at the growth $\mathrm{E}_{\mathrm{PAR}}$ (i.e., $100 \mu \mathrm{mol}$ photons $\mathrm{m}^{-2} \mathrm{~s}^{-1}$ ). 

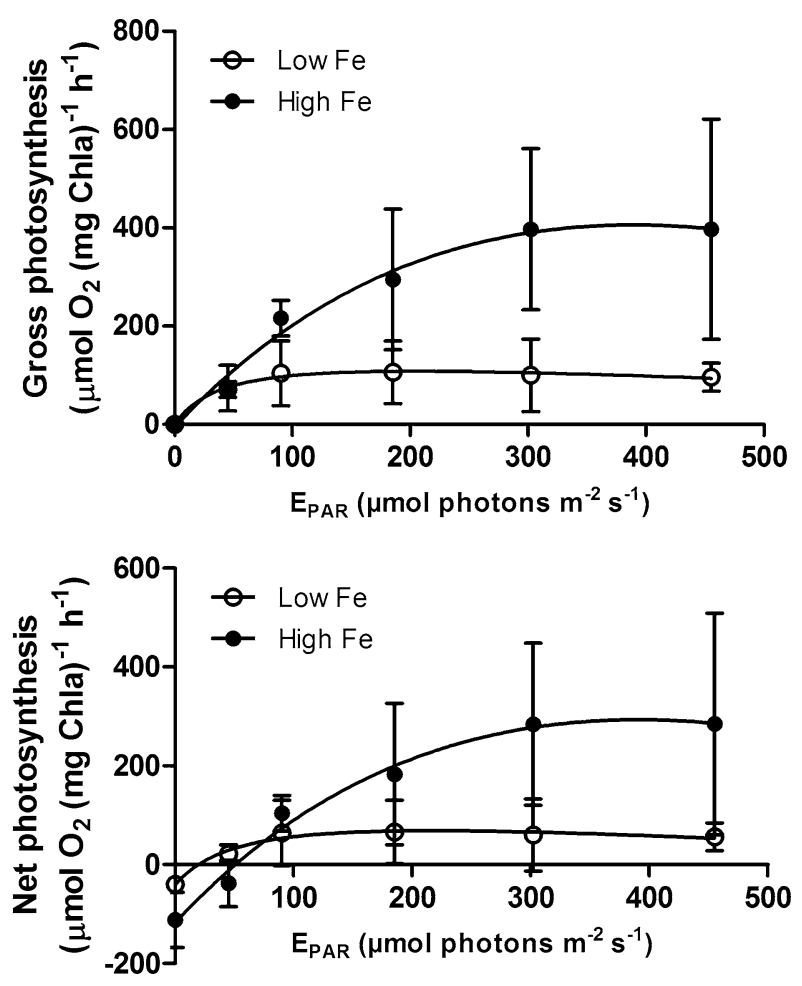

Fig. 3 Gross (a) and net (b) photosynthesis rates in Chaetoceros cf. simplex for Low $\mathrm{Fe}$ (open circle) and High $\mathrm{Fe}$ (filled circle) conditions. Values represent mean \pm standard deviation $(n=3)$

Table 3 Gross and net oxygen production (GP and NP, respectively), respiration (R) and GP:R were determined at $100 \mu \mathrm{mol}$ photons $\mathrm{m}^{-2} \mathrm{~s}^{-1}$ in Chaetoceros cf. simplex for Low Fe and High Fe conditions

\begin{tabular}{|c|c|c|}
\hline & Low Fe & High Fe \\
\hline $\begin{array}{l}\text { Gross oxygen production (GP) } \\
{\left[\mu \mathrm{mol} \mathrm{O}{ }_{2}(\mathrm{mg} \mathrm{Chla})^{-1} \mathrm{~h}^{-1}\right]}\end{array}$ & $99.4 \pm 65.5$ & $202.3 \pm 36.1$ \\
\hline $\begin{array}{l}\text { Net oxygen production (NP) } \\
{\left[\mu \mathrm{mol} \mathrm{O}_{2}(\mathrm{mg} \mathrm{Chla})^{-1} \mathrm{~h}^{-1}\right]}\end{array}$ & $59.6 \pm 65.5$ & $89.9 \pm 36.1$ \\
\hline $\begin{array}{l}\text { Respiration (R) } \\
{\left[\mu \mathrm{mol} \mathrm{O} \mathrm{O}_{2}(\mathrm{mg} \mathrm{Chla})^{-1} \mathrm{~h}^{-1}\right]}\end{array}$ & $-39.8 \pm 8.9$ & $-112.3 \pm 56.3^{*}$ \\
\hline $\mathrm{GP}: \mathrm{R}$ & $2.9 \pm 1.7$ & $2.7 \pm 1.6$ \\
\hline
\end{tabular}

Values represent mean \pm standard deviation $(n=3)$. Significant changes $(p<0.05$, ANOVA) relative to the Low Fe condition are denoted by *

Similarly, respiration $(\mathrm{R})$ was significantly lower in the Low Fe treatment compared to High Fe $(p<0.05$, Table 3$)$. Interestingly, the ratio of GP to R (GP:R, Table 3) showed no variations between treatments.

\section{Elemental composition, growth and cell size}

The content of particulate organic carbon (POC) and particulate organic nitrogen (PON) per cell varied

significantly between the two treatments (Table 4). Cell number normalized POC and PON contents were $18 \%$ $(p<0.01)$ and $28 \%(p<0.001)$ lower in low Fe than in High Fe treatments, respectively. When the POC values were normalized to cell volume, such differences between the two treatments were not visible anymore (Table 4). With decreasing $\mathrm{Fe}$ availability, cell number normalized POC production rates declined (Table 4) while this was not the case when normalized to cell volume. The molar carbon to nitrogen ratios, $\mathrm{C}: \mathrm{N}$, were slightly higher in cells grown in the Low $\mathrm{Fe}$ than in the High Fe treatment $(p<0.01$, Table 4$)$.

The growth rates of Chaetoceros cf. simplex were significantly lower, by $9 \%$, in the Low Fe treatment $(0.53$ day $\left.^{-1}\right)$ compared to the High Fe treatment $\left(0.58\right.$ day $\left.^{-1}\right)$ (Table 4). Correspondingly, the cell length/volume was also lower in Fe-deficient compared to Fe-enriched cells.

\section{Pigments}

Generally, the pigment content of Chaetoceros cf. simplex did not differ between both treatments, except for Chla, which was $20 \%$ lower in the Low Fe than in the High Fe treatment $(p<0.01)$, and for $B$-carotene, which was $43 \%$ lower in the Low Fe vs. High Fe treatment ( $p<0.001$; Table 5).

\section{Total dissolved iron concentrations and intracellular trace metals quotas}

The concentration of total $\mathrm{dFe}$ of the culture medium of the Low $\mathrm{Fe}$ and the High Fe treatments were significantly different $(p<0.0001)$, with $0.39 \pm 0.02$ and $3.07 \pm 0.13 \mathrm{nmol}$

Table 4 Elemental composition, growth rate and cell size of Chaetoceros cf. simplex for Low Fe and High Fe conditions

\begin{tabular}{|c|c|c|}
\hline & Low Fe & High Fe \\
\hline $\mathrm{POC}\left(\mathrm{pg} \mathrm{C} \mathrm{cell}^{-1}\right)$ & $7.63 \pm 0.42$ & $9.26 \pm 0.71^{*}$ \\
\hline $\mathrm{POC}_{\mathrm{vol}}\left(\operatorname{pg} \mathrm{C} \mu \mathrm{m}^{-3}\right)$ & $0.17 \pm 0.03$ & $0.16 \pm 0.01$ \\
\hline $\begin{array}{l}\text { Daily POC production rate } \\
\left(\mathrm{pg} \mathrm{C}^{-1} \text { cell }^{-1} \text { day }^{-1}\right)\end{array}$ & $4.04 \pm 0.20$ & $5.39 \pm 0.86^{*}$ \\
\hline 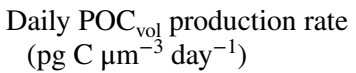 & $0.09 \pm 0.01$ & $0.09 \pm 0.01$ \\
\hline $\mathrm{PON}\left(\mathrm{pg} \mathrm{N}\right.$ cell $\left.^{-1}\right)$ & $1.37 \pm 0.06$ & $1.76 \pm 0.12 *$ \\
\hline $\mathrm{C}: \mathrm{N}\left(\mathrm{mol} \mathrm{mol}^{-1}\right)$ & $6.48 \pm 0.10$ & $6.12 \pm 0.16^{*}$ \\
\hline$\mu\left(\right.$ day $\left.^{-1}\right)$ & $0.53 \pm 0.02$ & $0.58 \pm 0.02 *$ \\
\hline Cell length $(\mu \mathrm{m})$ & $5.63 \pm 0.28$ & $6.44 \pm 0.11^{*}$ \\
\hline Cell volume $\left(\mu \mathrm{m}^{3}\right)$ & $46.37 \pm 5.75$ & $58.39 \pm 1.80^{*}$ \\
\hline
\end{tabular}

simplex for low $\mathrm{Fe}$ and high $\mathrm{Fe}$ conditions. Values represent mean \pm standard deviation $(n=3)$

Values represent mean \pm standard deviation $(n=3)$. Significant changes $(p<0.05$, ANOVA) relative to the low Fe condition are denoted by * 
Table 5 Cellular concentrations (fg cell ${ }^{-1}$ ) of the light harvesting pigments (LHP): chlorophyll a (Chla), chlorophyll $\mathrm{c}_{2}$ ( $\mathrm{Chl} \mathrm{c}_{2}$ ), fucoxanthin (Fuco), as well as of the light protective pigments (LPP): B-carotene (B-car), diadinoxanthin (Dd), diatoxanthin (Dt) and the ratio of LHP:LPP for Chaetoceros cf. simplex grown under Low Fe and High Fe conditions

\begin{tabular}{lll}
\hline & Low Fe & High Fe \\
\hline Chla & $126.5 \pm 8.8$ & $158.7 \pm 16.5^{*}$ \\
Chlc $_{2}$ & $17.9 \pm 1.7$ & $19.9 \pm 3.6$ \\
Fuco & $75.1 \pm 6.1$ & $80.5 \pm 12.0$ \\
B-car & $2.8 \pm 0.3$ & $4.9 \pm 0.6^{*}$ \\
Dd & $22.8 \pm 1.7$ & $25.5 \pm 8.2$ \\
Dt & $0.4 \pm 0.1$ & $0.5 \pm 0.3$ \\
LHP:LPP & $9.5 \pm 0.4$ & $10.5 \pm 2.7$ \\
\hline
\end{tabular}

Values represent mean \pm standard deviation $(n=3)$. Significant changes $(p<0.01$, ANOVA) in pigment concentrations relative to the Low Fe denoted by *

$\mathrm{L}^{-1}$, respectively (Fig. 4). Total $\mathrm{dFe}$ concentrations of the High Fe Chaetoceros cf. simplex incubation bottles were significantly reduced compared to the values of the culture medium High Fe bottles, indicating strong Fe uptake by the High Fe cells over the main experiment. Such uptake was not measured on the Low Fe treatments where no significant differences were found among the other trace metals (Table 6).

The carbon-normalized Fe quotas of Chaetoceros cf. simplex (expressed as $\mu \mathrm{mol} \mathrm{TM}$ :mol C, henceforth referred to as $\mu \mathrm{mol}: \mathrm{mol})$ showed a significant difference between Low Fe and High Fe cells (Fig. 5). The same trend was also observed in the cell-normalized TM quotas (Table 7, expressed as

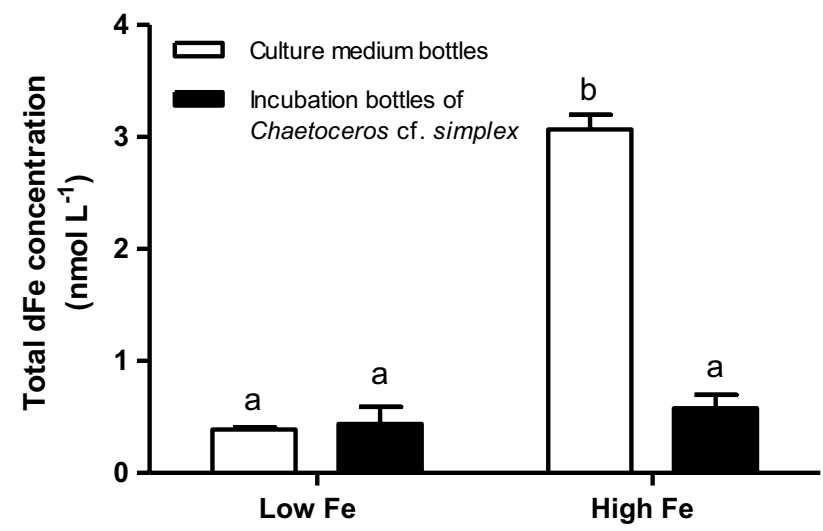

Fig. 4 Concentrations of total dissolved $\mathrm{Fe}(\mathrm{dFe})$ determined at the end of the main experiment. Concentrations were measured in the culture medium (white bars) and the incubation bottles of Chaetoceros cf. simplex cells (black bars), to which either no (Low $\mathrm{Fe}$ ) or a $4 \mathrm{nM} \mathrm{FeCl}_{3}$ spike was added. Data shown represent mean \pm standard deviation $(n \geq 3)$. Significant differences (ANOVA) for each parameter are denoted by different letters $(p<0.0001)$
Table 6 Concentrations of total dissolved iron, zinc, manganese, cobalt, and copper (in $\mathrm{nM}$ ) were determined in all incubation (with Chaetoceros cf. simplex cells) and culture medium (without cells) bottles of each treatment (Low Fe and High Fe) at the end of the experiments $(n \geq 3)$

\begin{tabular}{llllll}
\hline & \multicolumn{2}{l}{ Chaetoceros cf. simplex } & & \multicolumn{2}{l}{ Culture medium } \\
\cline { 2 - 3 } \cline { 5 - 6 } & Low Fe & High Fe & & Low Fe & High Fe \\
\hline $\mathrm{Fe}$ & $0.44 \pm 0.15$ & $0.58 \pm 0.12$ & & $0.39 \pm 0.02$ & $3.07 \pm 0.13^{* * * *}$ \\
$\mathrm{Zn}$ & $10.79 \pm 2.61$ & $9.55 \pm 3.23$ & & $10.55 \pm 0.70$ & $9.37 \pm 1.90$ \\
$\mathrm{Mn}$ & $0.56 \pm 0.25$ & $0.91 \pm 0.34$ & & $1.90 \pm 0.01$ & $1.82 \pm 0.02$ \\
$\mathrm{Co}$ & $0.48 \pm 0.01$ & $0.48 \pm 0.02$ & & $0.43 \pm 0.01$ & $0.43 \pm 0.02$ \\
$\mathrm{Cu}$ & $0.85 \pm 0.05$ & $0.87 \pm 0.06$ & & $0.96 \pm 0.05$ & $0.99 \pm 0.05$ \\
\hline
\end{tabular}

Significant changes in total dissolved trace metals concentrations of the High Fe relative to the Low Fe are denoted by $* * *(p<0.0001$, ANOVA)

amol cell ${ }^{-1}$ ). In contrast, $\mathrm{Zn}, \mathrm{Mn} \mathrm{Co}$ and $\mathrm{Cu}$ quotas were not significantly different between the two treatments.

\section{Discussion}

Fe is essential for redox-based reactions and is required for photosynthesis, respiration, and the nitrate and sulfur utilization pathways in phytoplankton (Behrenfeld and Milligan 2013; Raven 2013). Measuring both photosynthesis and respiration is essential in order to provide more accurate oceanic primary production rates, a key component of the global carbon cycle, as evident by different model scenarios (e.g. Tilzer and Dubinsky 1987; Lancelot et al. 1991; Arístegui et al. 1996; Quay et al. 2010). Recently it has been shown that the GP:R ratio is a critical parameter to assess the NPP depending on light and temperature conditions (Bozzato et al. 2019). The influence of GP:R ratios on NPP is seasonal-dependent. The present study confirms that also under Fe-limiting conditions the GP:R ratio must be taken into account to assess the real NPP. For the first time, this study presents a novel experimental approach, by combining both photosynthesis and respiration, in order to better understand the effects of Fe-limitation on carbon uptake in the SO. Since Fe is important for the proteins in the electron transport chain (ETC), Fe deficiency directly influences the photosynthetic performance of the cells (Behrenfeld and Milligan 2013). Also in this study, a strong response to $\mathrm{Fe}$ depletion was found in different physiological parameters, such as a lower Fv/Fm from 0.50 to 0.38 (Table 1) in the Chaetoceros species tested in this work. Similarly, the number of functional reaction centers per cell, $\mathrm{RCII}_{\text {cell }}$, as well as the connectivity between PSII, P, was lower under Low Fe compared to High Fe, a response commonly observed under Fe limitation (Petrou et al. 2014; Koch et al. 2019; Trimborn et al. 2019). Conversely, the functional absorption 

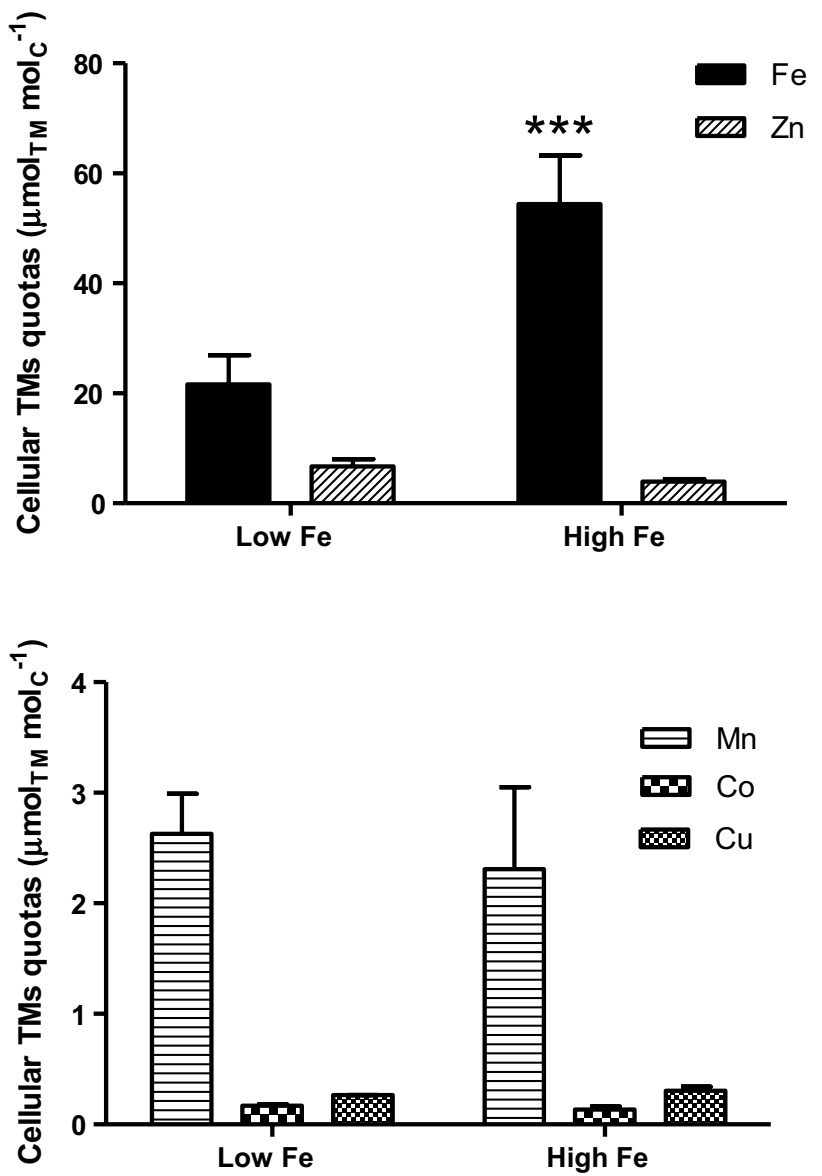

Fig. 5 Carbon normalized cellular quotas of a the trace metals iron $(\mathrm{Fe})$ and zinc $(\mathrm{Zn})$; b manganese $(\mathrm{Mn})$, copper $(\mathrm{Cu})$ and cobalt $(\mathrm{Co})$; for Chaetoceros cf. simplex grown under Low Fe and High Fe conditions. Values represent mean \pm standard deviation $(n=3)$. Significant differences for each parameter relative to the Low $\mathrm{Fe}$ are denoted by $* * *(p<0.0001$, ANOVA $)$

Table 7 Cellular contents of $\mathrm{Fe}, \mathrm{Zn}, \mathrm{Mn}, \mathrm{Co}$, and $\mathrm{Cu}$ (in amol cell ${ }^{-1}$ ) of Chaetoceros cf. simplex grown under Low Fe and High Fe conditions $(n=3, \# n=2)$

\begin{tabular}{lll}
\hline & Low Fe & High Fe \\
\hline $\mathrm{Fe}$ & $14.22 \pm 3.89^{\#}$ & $41.61 \pm 4.92^{* * *}$ \\
$\mathrm{Zn}$ & $4.30 \pm 1.01$ & $3.08 \pm 0.14^{\#}$ \\
$\mathrm{Mn}$ & $1.66 \pm 0.18$ & $1.75 \pm 0.47$ \\
$\mathrm{Co}$ & $0.11 \pm 0.00$ & $0.10 \pm 0.01$ \\
$\mathrm{Cu}$ & $0.17 \pm 0.01^{\#}$ & $0.24 \pm 0.04^{*}$ \\
\hline
\end{tabular}

Significant changes in intracellular trace metals quotas relative to the Low $\mathrm{Fe}$ are denoted by $* * *$ or $*$ (respectively, $p<0.0001$ and $p<0.05$, ANOVA)

cross sections of PSII, $\sigma_{\mathrm{PSII}}$ was higher in Fe-limited cells. Such a response is attributed to an increase in the ratio of antenna complexes relative to the reaction center core complexes (Greene et al. 1991). It has been suggested that SO phytoplankton species, in particular, counteract the diminished number of Fe-rich PS reaction centers with a larger $\sigma_{\text {PSII }}$ (Strzepek et al. 2012), as frequently observed for other Antarctic Chaetoceros species (Timmermans et al. 2001; van Oijen et al. 2004; Petrou et al. 2014; Trimborn et al. 2019).

Among the different subunits of the photosynthetic apparatus, PSI and cytochrome $b_{6} f$ have particularly high $\mathrm{Fe}$ requirements and represent the limiting components of the electron flow in the thylakoid membranes (Wilhelm and Wild 1984; Strzepek and Harrison 2004). Under Fe limitation, the required $\mathrm{Fe}$ cannot be replaced and the cytochrome complexes cannot be substituted by alternative electron carriers. Thus, Fe limitation strongly limited the capacity of aETR both at the growth $\mathrm{E}_{\mathrm{PAR}}$ (Table 2) and at light saturation $\left(\mathrm{aETR}_{\max }\right.$, Fig. 1) in the Low Fe compared to High Fe treatment, which led to a much earlier onset of light saturation, $E_{k}$, under Low Fe conditions (Table 2). This is in line with light saturation characteristics previously reported for the Fe limited Antarctic Chaetoceros simplex (Petrou et al. 2014). Fe is required in several ETC proteins and the limited Fe availability thus pushed the cell's physiological machinery to absorb less light. As a consequence of the lowered $\mathrm{Fe}$ availability, the Chaetoceros cells in the Low Fe treatment exhibited 60\% lower intracellular Fe content compared to High Fe cells (Table 7 and Fig. 5). In comparison, there was no difference in the TM quotas of $\mathrm{Zn}, \mathrm{Mn}, \mathrm{Co}$ and $\mathrm{Cu}$ between the two treatments.

The response of $\mathrm{O}_{2}$-based photosynthetic rates (NP and GP, Fig. 3) under Fe deficiency follows the same pattern as for the measured aETRs by Chla fluorescence (Fig. 1). Similarly, NP and GP at growth $\mathrm{E}_{\mathrm{PAR}}$ were much lower under Fe deficiency (Table 3), with even lower $\mathrm{GP}_{\max }$ and $\mathrm{NP}_{\max }$ in the Low Fe compared to High Fe treatment (Fig. 3). The differences in light-saturated GP could be accounted for by a lowered Rubisco content in the Low Fe cells. Indeed, it has already been shown that the relative abundance of the carboxylating enzyme Rubisco decreased in response to Fe starvation (Geider et al. 1993). Furthermore, Wilhelm and Wild (1984) showed that the amount of Rubisco and cytochrome $\mathrm{f}$ (cyt $\mathrm{f}$ ) are regulated in a coordinated manner and therefore the assumed Fe-dependent decrease of cyt $b_{6} f$ content fits well with the lower $\mathrm{GP}_{\max }$ under low Fe conditions observed in this study.

To the authors' knowledge, this is the first study combining $\mathrm{P}$ and $\mathrm{R}$ rates with daily $\mathrm{C}$ production of an $\mathrm{Fe}$-limited Antarctic diatom. Indeed, to illustrate the efficiency of the conversion of photosynthetic energy into $\mathrm{C}$ biomass production it is worthwhile to compare the photosynthetic rates (aETRs and GP) with the daily C production (Table 4) under Low $\mathrm{Fe}$ and High $\mathrm{Fe}$ conditions. It becomes evident that the inhibitory effect of Fe limitation was more pronounced for the photosynthetic energy production than for $\mathrm{C}$ biomass 
production. Moreover, when POC data are normalized to cell volume $\left(\mathrm{POC}_{\mathrm{vol}}\right.$, Table 4) rather than to cell number, an $\mathrm{Fe}$-dependent decrease in POC production is no longer visible (Daily $\mathrm{POC}_{\mathrm{vol}}$ production rate, Table 4). As has been observed in other diatoms (Timmermans et al. 2001; van de Poll et al. 2009; Alderkamp et al. 2012; Trimborn et al. 2019), Chaetoceros cf. simplex was able to strongly limit the number of electrons entering the ETC under Fe limitation (Fig. 1). In this way, an overexcitation of the ETC was prevented. This fits with the observed decrease of the light absorption capacity, as indicated by the significantly lower cellular Chla content in Low Fe cells (Table 5). In addition, the lower content of B-carotene in Low Fe relative to High Fe cells (Table 5) is in line with less functional PSII reaction centers (Tracewell et al. 2001). Lastly, the assumption that a decreased photosynthetic capacity limits the excitation pressure on the ETC is supported by the fact that Fe limited cells were neither forced to increase their extent of NPQ under saturating irradiance (Fig. 2) nor to increase their pool size of light protective pigments (LPP, Table 5). Moreover, the $P-E$ curve (Fig. 3 ) and the $\mathrm{Fv} / \mathrm{Fm}$ recovery rate (Table 2) did not reveal any indications for an increased sensitivity to high irradiances in cells under Low Fe conditions.

The absence of a difference in NPQ as a result of the different $\mathrm{Fe}$ availability is in contrast to the observations for Fe-limited cells of $C$. simplex made by Petrou et al. (2014). However, variations between the experimental setups should be considered. Firstly, the latter species was grown at a lower $\mathrm{E}_{\mathrm{PAR}}$ of $30 \mu \mathrm{mol}$ photons $\mathrm{m}^{-2} \mathrm{~s}^{-1}$, while the $\mathrm{E}_{\mathrm{PAR}}$ in the present study was much higher (i.e., $100 \mu \mathrm{mol}$ photons $\mathrm{m}^{-2} \mathrm{~s}^{-1}$ ). Secondly, the $\mathrm{NPQ}_{\max }$ values in Petrou et al. (2014) were obtained at an $\mathrm{E}_{\mathrm{PAR}} 4$ times higher than in this study (2260 vs. $492 \mu \mathrm{mol}$ photons $\mathrm{m}^{-2} \mathrm{~s}^{-1}$, respectively). Having a closer look at the data from Petrou et al. (2014), the NPQ values in the Fe limited $C$. simplex cells exposed to $500 \mu$ mol photons $\mathrm{m}^{-2} \mathrm{~s}^{-1}(\sim 0.1-0.2)$ were in a similar range as those of the Chaetoceros cf. simplex cells from this study.

Besides the simultaneous determination of photosynthesis rates by different methods (variable Chla fluorescence, oxygen evolution, $\mathrm{C}$ biomass production), a novel aspect of this study was the measurement of respiration rates in the Antarctic diatom Chaetoceros cf. simplex (Table 3). The Fe-limited conditions resulted in $65 \%$ lower $\mathrm{R}$ compared to High $\mathrm{Fe}$ conditions at the growth $\mathrm{E}_{\mathrm{PAR}}$ (Table 3). However, this did not result in any differences in the ratio of photosynthesis to respiration (GP:R, Table 3). This is not a trivial result, since studies investigating the photosynthetic activity of Antarctic phytoplankton are available (e.g. Palmisano et al. 1987; Petrou and Ralph 2011), whereas knowledge about carbon losses due to respiration is very scarce, mainly due to methodological limitations (e.g. Marra 2009; Moisan and Mitchell 2018). Data presented in the literature show a high variability in the ratio between photosynthesis and respiration (e.g. Vona et al. 2004). Furthermore, the cell size was also lower in the Low Fe vs. High Fe treatment (Table 4), which is a typical response found in Fe-limited cells (e.g. Stefels and van Leeuwe 1998). Thereby, the cells compensate for Fe deficiency and similar $\mathrm{POC}_{\mathrm{vol}}$ production rates between the two treatments were obtained (Table 4). Overall, these results indicate that the Fe limited cells showed a very efficient acclimation to the lowered assimilatory metabolism by decreasing their respiratory losses. This compensated for the inevitable reduced capacity for photosynthesis under Fe limitation.

Acknowledgements This work was supported by the Deutsche Forschungsgemeinschaft (DFG) in the framework of the priority programme "Antarctic Research with comparative investigations in Arctic ice areas" SPP 1158 by the following Grant WI 764/21-1. DB and CW were supported by grants from Deutsche Forschungsgemeinschaft (DFG, Grant WI 764/21-1). ST was funded by the Helmholtz Association (HGF Young Investigators Group EcoTrace, VH-NG-901). We thank T. Brenneis for laboratory assistance and C. Völkner for ICP-MS measurements. Thanks also to K. Bischof and B. Meier-Schlosser of the University of Bremen for the pigment analysis. We further thank the members of the EcoTrace as well as Marine Biogeosciences Group at the AWI for diverse logistical support. We are also grateful to Geir Johnsen and other two anonymous reviewers, who contributed to improve this manuscript with their valuable comments.

Author contributions DB performed and designed research, analysed data and wrote the manuscript. TJ, CW and ST designed research and reviewed the manuscript. CW and ST provided research opportunity.

Funding This work was supported by the Deutsche Forschungsgemeinschaft (DFG) in the framework of the priority programme "Antarctic Research with comparative investigations in Arctic ice areas" SPP 1158 by the following Grant WI 764/21-1. DB and CW were supported by grants from Deutsche Forschungsgemeinschaft (DFG, Grant WI 764/21-1). ST was funded by the Helmholtz Association (HGF Young Investigators Group EcoTrace, VH-NG-901).

Data availability All data are available within the publication.

\section{Compliance with ethical standards}

Conflict of interest The authors declare that they have no conflict of interest.

Open Access This article is licensed under a Creative Commons Attribution 4.0 International License, which permits use, sharing, adaptation, distribution and reproduction in any medium or format, as long as you give appropriate credit to the original author(s) and the source, provide a link to the Creative Commons licence, and indicate if changes were made. The images or other third party material in this article are included in the article's Creative Commons licence, unless indicated otherwise in a credit line to the material. If material is not included in the article's Creative Commons licence and your intended use is not permitted by statutory regulation or exceeds the permitted use, you will need to obtain permission directly from the copyright holder. To view a copy of this licence, visit http://creativecommons.org/licenses/by/4.0/. 


\section{References}

Alderkamp A-C, Kulk G, Buma AGJ, Visser RJW, van Dijken GL, Mills MM, Arrigo KR (2012) The effect of iron limitation on the photophysiolgy of Phaeocystis antarctica (Prymnesiophyceae) and Fragilariopsis Cylindrus (Bacillariophyceae) under dynamic irradiance. J Phycol 48:45-59. https://doi.org/10.111 1/j.1529-8817.2011.01098.x

Arístegui J, Montero MF, Ballesteros S, Basterretxea G, van Lenning K (1996) Planktonic primary production and microbial respiration measured by $14 \mathrm{C}$ assimilation and dissolved oxygen changes in coastal waters of the Antarctic Peninsula during austral summer:implications for carbon flux studies. Mar Ecol Prog Ser 132:191-201. https://doi.org/10.3354/meps132191

Arrigo KR, van Dijken GL (2003) Phytoplankton dynamics within 37 Antarctic coastal polynya systems. J Geophys Res 108:425. https ://doi.org/10.1029/2002JC001739

Arrigo KR, van Dijken GL, Bushinsky S (2008) Primary production in the Southern Ocean, 1997-2006. J Geophys Res 113:609. https:// doi.org/10.1029/2007JC004551

Behrenfeld MJ, Milligan AJ (2013) Photophysiological expressions of iron stress in phytoplankton. Ann Rev Mar Sci 5:217-246. https ://doi.org/10.1146/annurev-marine-121211-172356

Benson BB, Krause D (1984) The concentration and isotopic fractionation of oxygen dissolved in freshwater and seawater in equilibrium with the atmosphere1. Limnol Oceanogr 29:620-632. https://doi. org/10.4319/lo.1984.29.3.0620

Bilger W, Björkman O (1990) Role of the xanthophyll cycle in photoprotection elucidated by measurements of light-induced absorbance changes, fluorescence and photosynthesis in leaves of Hedera canariensis. Photosynth Res 25:173-185. https://doi.org/10.1007/ BF00033159

Biller DV, Bruland KW (2012) Analysis of Mn, Fe Co, Ni, Cu, Zn, $\mathrm{Cd}$, and $\mathrm{Pb}$ in seawater using the Nobias-chelate PA1 resin and magnetic sector inductively coupled plasma mass spectrometry (ICP-MS). Mar Chem 130-131:12-20. https://doi.org/10.1016/j. marchem.2011.12.001

Boyd PW, Jickells T, Law CS, Blain S, Boyle EA, Buesseler KO, Coale KH, Cullen JJ, de Baar HJW, Follows M, Harvey M, Lancelot C, Levasseur M, Owens NPJ, Pollard R, Rivkin RB, Sarmiento J, Schoemann V, Smetacek V, Takeda S, Tsuda A, Turner S, Watson AJ (2007) Mesoscale iron enrichment experiments 1993-2005: synthesis and future directions. Science 315:612-617. https://doi. org/10.1126/science.1131669

Bozzato D (2019) The effect of climate change on the carbon balance between photosynthesis and respiration in Antarctic microalgae. Dissertation, University of Leipzig

Bozzato D, Jakob T, Wilhelm C (2019) Effects of temperature and salinity on respiratory losses and the ratio of photosynthesis to respiration in representative Antarctic phytoplankton species. PLoS ONE 14:e0224101. https://doi.org/10.1371/journal.pone.0224101

Cutter G, Casciotti K, Croot P, Geibert W, Heimbürger L-E, Lohan M, Planquette H, van de Flierdt T (2017) Sampling and samplehandlingprotocols for GEOTRACES Cruises. Version 3, August 2017. https://doi.org/10.25607/OBP-2

Eilers P, Peeters J (1988) A model for the relationship between light intensity and the rate of photosynthesis in phytoplankton. Ecol Model 42:199-215. https://doi.org/10.1016/0304-3800(88)90057 $-9$

Fanesi A, Wagner H, Becker A, Wilhelm C (2016) Temperature affects the partitioning of absorbed light energy in freshwater phytoplankton. Freshw Biol 61:1365-1378. https://doi.org/10.1111/ fwb. 12777

Feng Y, Hare CE, Rose JM, Handy SM, DiTullio GR, Lee PA, Smith WO, Peloquin J, Tozzi S, Sun J, Zhang Y, Dunbar RB, Long MC,
Sohst B, Lohan M, Hutchins DA (2010) Interactive effects of iron, irradiance and $\mathrm{CO}_{2}$ on Ross Sea phytoplankton. Deep Sea Res I 57:368-383. https://doi.org/10.1016/j.dsr.2009.10.013

Geider RJ, Roche J, Greene RM, Olaizola M (1993) Response of the photosynthetic apparatus of Phaeodactylum Tricornutum (Bacillariophyaceae) to nitrate, phosphate, or iron starvation. J Phycol 29:755-766. https://doi.org/10.1111/j.0022-3646.1993.00755.x

Geider RJ, Maclntyre HL, Kana TM (1998) A dynamic regulatory model of phytoplanktonic acclimation to light, nutrients, and temperature. Limnol Oceanogr 43:679-694. https://doi.org/10.4319/ lo.1998.43.4.0679

Gleitz M, Thomas DN (1992) Physiological responses of a small Antarctic diatom (Chaetoceros sp.) to simulated environmental constraints associated with sea-ice formation. Mar Ecol Prog Ser 88:271-278

Greene RM, Geider RJ, Falkowski PG (1991) Effect of iron limitation on photosynthesis in a marine diatom. Limnol Oceanogr 36:17721782. https://doi.org/10.4319/lo.1991.36.8.1772

Gruber N, Landschützer P, Lovenduski NS (2019) The variable Southern Ocean carbon sink. Ann Rev Mar Sci 11:159-186. https://doi. org/10.1146/annurev-marine-121916-063407

Guillard RRL, Ryther JH (1962) Studies of marine planktonic diatoms. I. Cyclotella nana Hustedt, and Detonula confervacea (cleve) Gran. Can J Microbiol 8:229-239. https://doi.org/10.1139/ m62-029

Hassler CS, Schoemann V (2009) Discriminating between intra- and extracellular metals using chemical extractions: an update on the case of iron. Limnol Oceanogr Methods 7:479-489. https://doi. org/10.4319/lom.2009.7.479

Hillebrand H, Dürselen C-D, Kirschtel D, Pollingher U, Zohary $\mathrm{T}$ (1999) Biovolume calculation for pelagic and benthic microalgae. J Phycol 35:403-424. https://doi.org/10.104 6/j.1529-8817.1999.3520403.x

Ho T-Y, Quigg A, Finkel ZV, Milligan AJ, Wyman K, Falkowski PG, Morel FMM (2003) The elemental composition of some marine phytoplankton. J Phycol 39:1145-1159. https://doi. org/10.1111/j.0022-3646.2003.03-090.x

Hoppe CJM, Hassler CS, Payne CD, Tortell PD, Rost B, Trimborn S (2013) Iron limitation modulates ocean acidification effects on southern ocean phytoplankton communities. PLoS ONE 8:e79890. https://doi.org/10.1371/journal.pone.0079890

Hoppe CJM, Schuback N, Semeniuk D, Giesbrecht K, Mol J, Thomas H, Maldonado MT, Rost B, Varela DE, Tortell PD (2018) Resistance of Arctic phytoplankton to ocean acidification and enhanced irradiance. Polar Biol 41:399-413. https://doi.org/10.1007/s0030 0-017-2186-0

Horton P, Ruban AV, Walters RG (1994) Regulation of light harvesting in green plants (indication by nonphotochemical quenching of chlorophyll fluorescence). Plant Physiol 106:415-420. https:// doi.org/10.1146/annurev.arplant.47.1.655

Koch F, Beszteri S, Harms L, Trimborn S (2019) The impacts of iron limitation and ocean acidification on the cellular stoichiometry, photophysiology, and transcriptome of Phaeocystis antarctica. Limnol Oceanogr 64:357-375. https://doi.org/10.1002/lno.11045

Kolber ZS, Prášil O, Falkowski PG (1998) Measurements of variable chlorophyll fluorescence using fast repetition rate techniques: defining methodology and experimental protocols. Biochim Biophy Acta (BBA) 1367:88-106. https://doi.org/10.1016/S0005 -2728(98)00135-2

Kropuenske LR, Mills MM, van Dijken GL, Bailey S, Robinson DH, Welschmeyer NA, Arrigoa KR (2009) Photophysiology in two major Southern Ocean phytoplankton taxa: Photoprotection in Phaeocystis antarctica and Fragilariopsis cylindrus. Limnol Oceanogr 54:1176-1196. https://doi.org/10.4319/ lo.2009.54.4.1176 
Lancelot C, Billen G, Veth C, Becquevort S, Mathot S (1991) Modelling carbon cycling through phytoplankton and microbes in the Scotia-Weddell Sea area during sea ice retreat. Mar Chem 35:305-324. https://doi.org/10.1016/S0304-4203(09)90024-X

Laws EA, Bannister TT (1980) Nutrient- and light-limited growth of Thalassiosira fluviatilis in continuous culture, with implications for phytoplankton growth in the ocean. Limnol Oceanogr 25:457473. https://doi.org/10.4319/lo.1980.25.3.0457

Marra J (2009) Net and gross productivity: weighing in with ${ }^{14} \mathrm{C}$. Aquat Microb Ecol 56:123-131. https://doi.org/10.3354/ame01306

Moisan TA, Mitchell BG (2018) Modeling net growth of Phaeocystis antarctica based on physiological and optical responses to light and temperature co-limitation. Front Mar Sci 4:365. https://doi. org/10.3389/fmars.2017.00437

Murata N, Takahashi S, Nishiyama Y, Allakhverdiev SI (2007) Photoinhibition of photosystem II under environmental stress. Biochim Biophys Acta 1767:414-421. https://doi.org/10.1016/j.bbabi o.2006.11.019

Palmisano AC, Beeler SooHoo J, Sullivan CW (1987) Effects of four environmental variables on photosynthesis-irradiance relationships in Antarctic sea-ice microalgae. Mar Biol 94:299-306. https ://doi.org/10.1007/BF00392944

Pankowski A, McMinn A (2009) Iron availability regulates growth, photosynthesis, and production of ferredoxin and flavodoxin in Antarctic sea ice diatoms. Aquat Biol 4:273-288. https://doi. org/10.3354/ab00116

Petrou K, Ralph PJ (2011) Photosynthesis and net primary productivity in three Antarctic diatoms: possible significance for their distribution in the Antarctic marine ecosystem. Mar Ecol Prog Ser 437:27-40. https://doi.org/10.3354/meps09291

Petrou K, Trimborn S, Rost B, Ralph PJ, Hassler CS (2014) The impact of iron limitation on the physiology of the Antarctic diatom Chaetoceros simplex. Mar Biol 161:925-937. https://doi.org/10.1007/ s00227-014-2392-z

Quay PD, Peacock C, Björkman K, Karl DM (2010) Measuring primary production rates in the ocean: enigmatic results between incubation and non-incubation methods at station ALOHA. Glob Biogeochem Cycles. https://doi.org/10.1029/2009GB003665

Raven JA (2013) Iron acquisition and allocation in stramenopile algae. J Exp Bot 64:2119-2127. https://doi.org/10.1093/jxb/ert121

Regaudie-de-Gioux A, Duarte CM (2012) Temperature dependence of planktonic metabolism in the ocean. Glob Biogeochem Cycles. https://doi.org/10.1029/2010GB003907

Sarthou G, Timmermans KR, Blain S, Tréguer P (2005) Growth physiology and fate of diatoms in the ocean: a review. J Sea Res 53:25-42. https://doi.org/10.1016/j.seares.2004.01.007

Serret P, Robinson C, Aranguren-Gassis M, García-Martín EE, Gist N, Kitidis V, Lozano J, Stephens J, Harris C, Thomas R (2015) Both respiration and photosynthesis determine the scaling of plankton metabolism in the oligotrophic ocean. Nat Commun 6:6961. https ://doi.org/10.1038/ncomms7961

Smetacek V, Klaas C, Strass VH, Assmy P, Montresor M, Cisewski B, Savoye N, Webb A, d'Ovidio F, Arrieta JM, Bathmann U, Bellerby R, Berg GM, Croot P, Gonzalez S, Henjes J, Herndl GJ, Hoffmann LJ, Leach H, Losch M, Mills MM, Neill C, Peeken I, Röttgers R, Sachs O, Sauter E, Schmidt MM, Schwarz J, Terbrüggen A, Wolf-Gladrow D (2012) Deep carbon export from a Southern Ocean iron-fertilized diatom bloom. Nature 487:313319. https://doi.org/10.1038/nature11229

Stefels J, van Leeuwe MA (1998) Effects of iron and light stress on the biochemical composition of Antarctic Phaeocystis sp. (Prymnesiophyceae). I. Intracellular DMSP concentrations. J Phycol 34:486-495. https://doi.org/10.1046/j.1529-8817.1998.340486.x

Strzepek RF, Harrison PJ (2004) Photosynthetic architecture differs in coastal and oceanic diatoms. Nature 431:689-692. https://doi. org/10.1038/nature02954
Strzepek RF, Hunter KA, Frew RD, Harrison PJ, Boyd PW (2012) Iron-light interactions differ in Southern Ocean phytoplankton. Limnol Oceanogr 57:1182-1200. https://doi.org/10.4319/ lo.2012.57.4.1182

Suggett DJ, MacIntyre HL, Geider RJ (2004) Evaluation of biophysical and optical determinations of light absorption by photosystem II in phytoplankton. Limnol Oceanogr Methods 2:316-332. https:// doi.org/10.4319/lom.2004.2.316

Suggett DJ, Moore CM, Hickman AE, Geider RJ (2009) Interpretation of fast repetition rate (FRR) fluorescence: signatures of phytoplankton community structure versus physiological state. Mar Ecol Prog Ser 376:1-19. https://doi.org/10.3354/meps07830

Takao S, Hirawake T, Wright SW, Suzuki K (2012) Variations of net primary productivity and phytoplankton community composition in the Indian sector of the Southern Ocean as estimated from ocean color remote sensing data. Biogeosciences 9:3875-3890. https://doi.org/10.5194/bg-9-3875-2012

Thomas DN, Baumann ME, Gleitz M (1992) Efficiency of carbon assimilation and photoacclimation in a small unicellular Chaetoceros species from the Weddell Sea (Antarctica): influence of temperature and irradiance. J Exp Mar Biol Ecol 157:195-209. https://doi.org/10.1016/0022-0981(92)90162-4

Tilzer MM, Dubinsky Z (1987) Effects of temperature and day length on the mass balance of Antarctic phytoplankton. Polar Biol 7:3542. https://doi.org/10.1007/BF00286822

Timmermans KR, Davey MS, van der Wagt B, Snoek J, Geider RJ, Veldhuis MJ, Gerringa LJ, de Baar HJ (2001) Co-limitation by iron and light of Chaetoceros brevis, C. dichaeta and C. calcitrans (Bacillariophyceae). Mar Ecol Prog Ser 217:287-297. https://doi. org/10.3354/meps217287

Tortell PD, Payne CD, Li Y, Trimborn S, Rost B, Smith WO, Riesselman C, Dunbar RB, Sedwick P, DiTullio GR (2008) $\mathrm{CO}_{2}$ sensitivity of Southern Ocean phytoplankton. Geophys Res Lett 35:15587. https://doi.org/10.1029/2007GL032583

Tracewell CA, Vrettos JS, Bautista JA, Frank HA, Brudvig GW (2001) Carotenoid photooxidation in photosystem II. Arch Biochem Biophys 385:61-69. https://doi.org/10.1006/abbi.2000.2150

Tréguer P, Bowler C, Moriceau B, Dutkiewicz S, Gehlen M, Aumont O, Bittner L, Dugdale R, Finkel Z, Iudicone D, Jahn O, Guidi L, Lasbleiz M, Leblanc K, Levy M, Pondaven P (2018) Influence of diatom diversity on the ocean biological carbon pump. Nat Geosci 11:27-37. https://doi.org/10.1038/s41561-017-0028-x

Trimborn S, Thoms S, Petrou K, Kranz SA, Rost B (2014) Photophysiological responses of Southern Ocean phytoplankton to changes in $\mathrm{CO}_{2}$ concentrations: short-term versus acclimation effects. J Exp Mar Biol Ecol 451:44-54. https://doi.org/10.1016/j.jembe .2013 .11 .001

Trimborn S, Hoppe CJ, Taylor BB, Bracher A, Hassler C (2015) Physiological characteristics of open ocean and coastal phytoplankton communities of Western Antarctic Peninsula and Drake Passage waters. Deep Sea Res I 98:115-124. https://doi.org/10.1016/j. dsr.2014.12.010

Trimborn S, Brenneis T, Hoppe CJ, Laglera LM, Norman L, SantosEcheandía J, Völkner C, Wolf-Gladrow D, Hassler CS (2017) Iron sources alter the response of Southern Ocean phytoplankton to ocean acidification. Mar Ecol Prog Ser 578:35-50. https://doi. org/10.3354/meps 12250

Trimborn S, Thoms S, Bischof K, Beszteri S (2019) Susceptibility of two southern ocean phytoplankton key species to iron limitation and high light. Front Mar Sci 6:1248. https://doi.org/10.3389/ fmars.2019.00167

Twining BS, Baines SB (2013) The trace metal composition of marine phytoplankton. Ann Rev Mar Sci 5:191-215. https://doi. org/10.1146/annurev-marine-121211-172322

van de Poll WH, Janknegt PJ, van Leeuwe MA, Visser RJW, Buma AGJ (2009) Excessive irradiance and antioxidant responses of 
an Antarctic marine diatom exposed to iron limitation and to dynamic irradiance. J Photochem Photobiol B 94:32-37. https:// doi.org/10.1016/j.jphotobiol.2008.09.003

van de Poll WH, Lagunas M, de Vries T, Visser RJ, Buma AG (2011) Non-photochemical quenching of chlorophyll fluorescence and xanthophyll cycle responses after excess PAR and UVR in Chaetoceros brevis, Phaeocystis antarctica and coastal Antarctic phytoplankton. Mar Ecol Prog Ser 426:119-131. https://doi. org/10.3354/meps09000

van Oijen T, van Leeuwe MA, Gieskes WWC, de Baar HJW (2004) Effects of iron limitation on photosynthesis and carbohydrate metabolism in the Antarctic diatom Chaetoceros brevis (Bacillariophyceae). Eur J Phycol 39:161-171. https://doi. org/10.1080/0967026042000202127

Verity PG (1982) Effects of temperature, irradiance, and daylength on the marine diatom Leptocylindrus danicus Cleve. III. Dark respiration. J Exp Mar Biol Ecol 60:197-207. https://doi. org/10.1016/0022-0981(82)90159-9

Vona V, Di Martino RV, Lobosco O, Carfagna S, Esposito S, Rigano C (2004) Temperature responses of growth, photosynthesis, respiration and NADH: nitrate reductase in cryophilic and mesophilic algae. New Phytol 163:325-331. https://doi.org/10.111 1/j.1469-8137.2004.01098.x

Wilhelm C, Wild A (1984) The variability of the photosynthetic unit in Chlorella II. the effect of light intensity and cell development on photosynthesis, P-700 and cytochrome $\mathrm{f}$ in homocontinuous and synchronous cultures of Chlorella. J Plant Physiol 115:125-135. https://doi.org/10.1016/S0176-1617(84)80059-0

Wright SW, Jeffrey SW, Mantoura RF, Llewellyn CA, Bjornland T, Repeta D, Welschmeyer N (1991) Improved HPLC method for the analysis of chlorophylls and carotenoids from marine phytoplankton. Mar Ecol Prog Ser 77:183-196. https://doi.org/10.3354/ meps077183

Yoon J-E, Yoo K-C, Macdonald AM, Yoon H-I, Park K-T, Yang EJ, Kim H-C, Lee JI, Lee MK, Jung J, Park J, Lee J, Kim S, Kim S-S, Kim K, Kim I-N (2018) Reviews and syntheses: ocean iron fertilization experiments-past, present, and future looking to a future Korean Iron Fertilization Experiment in the Southern Ocean (KIFES) project. Biogeosciences 15:5847-5889. https:// doi.org/10.5194/bg-15-5847-2018

Zhu Z, Xu K, Fu F, Spackeen JL, Bronk DA, Hutchins DA (2016) A comparative study of iron and temperature interactive effects on diatoms and Phaeocystis antarctica from the Ross Sea. Antarct Mar Ecol Prog Ser 550:39-51. https://doi.org/10.3354/meps11732

Publisher's Note Springer Nature remains neutral with regard to jurisdictional claims in published maps and institutional affiliations. 